\title{
The Effect of Knowledge Management Processes on Project Management
}

\author{
An Empirical Study on Information Technology Industry in Jordan
}

\author{
Abdel Naser Al-Zayyat ${ }^{1}$, Firas Al-Khaldi ${ }^{2}$, Ibrahem Tadros ${ }^{3}$ and Ghassan Al-Edwan ${ }^{3}$ \\ ${ }^{1}$ Applied science university Amman-Jordan \\ ${ }^{2}$ The Arab Academy for Banking and Financial Sciences Amman-Jordan \\ ${ }^{3}$ Al-Balqa applied university Amman-Jordan
}

\begin{abstract}
Knowledge management and project management are recognized to be of supreme importance to the competitive advantage of organizations as well as a major agent of change in the new era of the knowledge economy. This study empirically examines the relationship between knowledge management processes and project management in the context of the information technology industry in Jordan.

Very frequently projects, mostly information technology (IT) projects, fail or are challenged due to their incapability to get the right knowledge to the right people at the right time, and help people on the project share and put information into action in ways, which improve project performance. Knowledge management may be able to address this. Previous studies have not clearly identified nor demonstrated the relationship between the management of projects and the use of knowledge management processes. The purpose of this research is to identify if a positive relationship exists between the two? If a relationship does exist, which knowledge management processes in use by practitioners of project management are significant in terms of improving project management, and what is their impact? Hundred and fourteen project practitioners (project managers, managers, team leaders, team members, supervisors, etc) some affiliated with the Project Management Institute (PMI), and mostly from organizations in the IT industry both governmental and private had participated in the research to answer these questions. A positivistic approach was adapted using quantitative data. A survey aimed at project practitioners of information technology industry population was conducted in an effort to investigate the knowledge management activities and to examine the relationship of knowledge management processes and the improvement of project management.
\end{abstract}

Keywords: 3-4 keywords that highlight the topic in the paper

\section{Introduction}

With the advent of the Information Age the construct of knowledge management came into being and has given rise to a proliferation of research and publications in the academic and business realms of management. (Ruggles, 1998) wrote that 'knowledge has become the key economic resource and the dominant -- and perhaps even the only -- source of comparative advantage'. In this statement two concepts -knowledge as an economic resource and knowledge as a source of competitive advantage -- made significant impact on the traditional management approach and demanded a paradigm shift. This in turn created an abundance of new constructs and concepts -like intellectual capital, human capital, structural capital, knowledge capital, customer capital, human intellectual assets, intangible assets, knowledge worker, and competent employee -- all emphasizing the utilization of a scarce and special kind of human resource Garel G, Giard V, Midler C. (2002).

Organizations realized that knowledge is the key asset for competitiveness and they have to deal with this emphasis on knowledge in their

Copyright (C) 2010 abdel Naser Al-Zayyat, Firas Al-Khaldi, Ibrahem Tadros and Ghassan Al-Edwan. This is an open access article distributed under the Creative Commons Attribution License unported 3.0, which permits unrestricted use, distribution, and reproduction in any medium, provided that original work is properly cited. The article is a reprint from a 2009 article. Contact author: Abdel Naser Al-Zayyat. E-mail: naserzayyat@yahoo.com 
business Bettoni, M. \& Schneider, S. (2002). In the knowledge-based economy knowledge is considered a primary factor which leads to competitive advantage. One way of doing this is through the management of knowledge. In other words, it is to deal astutely with knowledge, which has been stressed by Senge (1990), Drucker (1993), Toffler (1993), Nonaka and Takeuchi (1995) and Leonard-Barton (1995).

Many organizations begin their knowledge management efforts by trying to understand what they know and where that knowledge is. Knowledge management literature is often focusing on IT, where knowledge should be codified, systemized and standardized Davidson and Philip Voss (2002). Hence, many organizations have responded to the challenge of knowledge management by implementing IT systems while ignoring the cultural aspects, which influence how people behave around knowledge (Davenport \& Prusak, 1998). Evidently, this leads to the question if knowledge management efforts should not be much more than IT? In this research, the standpoint will be that knowledge management is more than just IT.

According to the Standish Group's paper "Extreme CHAOS 2001", only 28 percent of all information technology (IT) projects are considered successful; 23 percent are considered failed; and 49 percent are considered challenged (Boucher, et, al, 2001). The Standish Group defines the categories of project success, failure and challenged as follows:

Successful: The project is completed on time and on budget, with all features and functions originally specified.

Challenged: The project is completed and operational, but over budget, late, and with fewer features and functions than initially specified.

Failed: The project is cancelled before completion, or never implemented.

(Standish Group, 2001) indicated that the main reasons for project failure include lack of:

1- Executive support 2- User involvement 3Experienced project manager

4- Clear business objectives 5- Scope control 6Standard software infrastructure 7- Baseline requirements 8- Formal methodology 9Reliable estimates projects

Project success is achieved by improved risk management enabled by knowledge management. Risk management is the means by which uncertainty is systematically managed to increase the likelihood of meeting project objectives (Verzuh 1999). The management of this uncertainty is dependent upon the "awareness" of "accessibility" of the knowledge available Colgate, M. (1996).

\section{The Main Subject}

Mark W. McElroy (2000) introduced three fundamental knowledge processes are: knowledge production, knowledge validation, knowledge integration. Related to Mcelroy work, the researcher notice the following, his first process knowledge production corresponds to knowledge creation, capture, and sharing because it involves creation of new ideas \& new insights (creation), acquisition of knowledge from outside sources (capture), and interaction between people (sharing). His second process knowledge validation is a new phase in knowledge life cycle because it involves testing the value of knowledge in practice which isn't mentioned before by any researcher in knowledge life cycle. In his third process knowledge integration, he mentioned that codification and transfer are happen in this process, also it involves implementation of knowledge throughout the organization, and i.e. knowledge integration corresponds to knowledge application at Nissen, Davidson, and Parikh.

To support understanding the relationship between improving the management of projects and the use of knowledge management processes Alkhaldi, F. M. (2003), it is important that this literature review investigate the three (3) following questions:

1) What has been done so far to improve the profession of project management?

2) What is knowledge management all about?

3) Has been any research or studies to date concerning improving the management of projects and the use of knowledge management processes?

\section{What has been done so far to improve the profession of project management?}

Numerous articles, books, studies, and white papers demonstrate the efforts of those in academia, government, industry, and professional organizations to improve the profession of project management. Their quarrel includes but is not limited to improving the management of project scope, cost, risk, human resources, schedule, communications, and procurement. In particular, numerous quality 
management initiatives have contributed directly or indirectly to improve project initiation, planning, execution, and control. These quality management initiatives include:

- Six Sigma

- Total Quality Management (TQM)

- Software Engineering Institute (SEI) Capability Maturity Model (CMM)

- International Organization for Standardization (ISO) 9000 and 10000 series of standards and guidelines

- Created by an appropriate diverse group through an open consensus building process; and

- Covering commonly accepted knowledge a/or practices and dealing with core concepts for the practice of the project management profession."

The most recently released and most relevant standard to this study from PMI is the Organizational Project Management Maturity Model $\left(\mathrm{OPM}^{\mathrm{TM}}\right)$. "The purpose of this standard is to provide a way for organizations to understand organizational project management and to measure their organizational project management maturity against a comprehensive and broad-based set of organizational project management Best Practices" (OPM3 $^{\text {тм }}$ Knowledge Foundation p. xiii). $\mathrm{OPM}^{\mathrm{TM}}$ has almost 600 Best Practices (OPM3 M Knowledge Foundation p. xiv). "Organizational project management is the application of knowledge, skills, tools, and techniques to organizational and project activities to achieve the aims of the organization through projects" (OPM3 $^{\text {TM }}$ Knowledge Foundation p. 5). "Organizational project management maturity is the degree to which an organization practices this type of project management" (OPM3"' Knowledge Foundation p. 5). "PMI's vision is that OPM3 ${ }^{\mathrm{TM}}$ becomes recognized world-wide as the standard for developing and assessing project management capabilities within any organization" (PMI, 2002, PMI Global Assembly Presentation, slide 34).

\section{What is the history of knowledge management?}

In the early 1970s Knowledge management academic-based research started and focused on the dispersal of innovation and information and technology transfer. These efforts donated to the understanding of how knowledge is formed, used, and dispersed within organizations.
By the mid-1980s, the importance of knowledge as a competitive asset became more perceptible; however, there was a concern over how to deal with the large increases in the amount of available knowledge and increasingly complex products and processes. Computer technology which contributed so heavily to the accumulation of information started to help address the issue. The 1980s saw the development of systems for managing knowledge that relied on work done in artificial intelligence and expert systems. This resulted in concepts such as "knowledge acquisition," "knowledge engineering," and "knowledgebased systems" (Barclay, R. and Murray, P., 2004). To provide a technological base for managing knowledge, a consortium of companies in the United States started the Initiative for Managing Knowledge Assets in 1989 (Barclay, R. and Murray, P., 2004). Knowledge management organizations such as the International Knowledge Management Network (IKMN), which began in Europe, the U.S.-based Knowledge Management Forum, in addition to other knowledge managementrelated groups started to be become established during this timeframe too (Barclay, R. and Murray, P., 2004).

\section{How can knowledge management really improve project management?}

In order for knowledge management to improve project management, whenever a project is initiated, content, processes, technology, and most importantly people need to be considered (Kelly, J., 2003). This literature review explores these things with emphasis on the "awareness " of and "accessibility " of knowledge, particularly in the studied project management activities

\section{Purpose of the study}

The purpose of this research is to analyze the successful broadcasting of knowledge and how it improves project management. The researcher wish to determine if there is a significant relationship between improvements for the management of projects and the use of Knowledge Management processes. The researcher wish to investigate whether knowledge processes are responsible for improvement in the management of projects. For the purpose of this research a successful project is defined as a project completed on time, within budget, met business and technical requirements, and therefore fulfilled the organizational objectives that define a successful project. A desired outcome is to identify the importance of knowledge management in the management of projects among project practitioners. 


\section{Research Questions}

To achieve the goals of this research, the following questions will be studied:

1. Is there a direct positive relationship between improving processes and the improvement of knowledge management?

2. Is there a direct positive relationship between Knowledge Management activities (5 C's) and Project Management improvement?

If a positive relationship exists per the aforementioned question, the secondary Purpose of the study will be to identify:

1. Which knowledge management practices throughout the lifecycle of KM (the 5 C's model) used by practitioners of project management were significant in terms of improving project management?

2. What is the impact of these knowledge management practices used by practitioners on improving the management of projects.

Sample reference entries for journal articles [1], books [2], edited books [3], and the Internet [4] are given in the References section.

\section{The major proposition of the research}

Three major propositions were developed to satisfy the objectives of this research. These propositions were designed to test the autonomous and the shared effect that the knowledge management processes have on the seven activities of project management:

\begin{tabular}{|c|c|c|c|c|c|c|c|}
\hline & \multicolumn{2}{|c|}{$\begin{array}{c}\text { Unstandardized } \\
\text { Coefficients }\end{array}$} & $\begin{array}{c}\text { Standardized } \\
\text { Coefficients }\end{array}$ & $\mathrm{t}$ & sig. & \multicolumn{2}{|c|}{ Collinearity Statistics } \\
\hline & $\mathrm{B}$ & Std. Error & Beta & & & Tolerance & VIF \\
\hline (Constant) & 1.535 & .490 & & 3.132 & 002 & & \\
\hline varc1k & -.100 & .115 & -.103 & -.868 & 387 & & 2.027 \\
\hline varc2k & .371 & .128 & .310 & 2.905 & 004 & .613 & 1.631 \\
\hline varc3k & .084 & .156 & .068 & .539 & 591 & .435 & 2.298 \\
\hline varc4k & .436 & .128 & .380 & 3.401 & 001 & .562 & 1.780 \\
\hline varc5k & -.216 & .168 & -.191 & -1.291 & 199 & .321 & 3.118 \\
& & & & & & & \\
\hline
\end{tabular}

P1: There is no direct positive relationship between increasing Process reusability (PM1), and the use of Knowledge Management (KM1)

P2: There is no direct positive relationship between Artifacts Reusability (PM2), and the use of Knowledge Management (KM1)

P3: There is no direct positive relationship between Scheduling (PM3), and the use of Knowledge Management (KM1)

\section{Hypothesis Testing}

\section{First hypothesis:}

H0: There is no direct positive relationship between increasing Process reusability (PM1), and the use of Knowledge Management (KM1)

H1: There is a direct positive relationship between increasing Process reusability (PM1), and the use of Knowledge Management (KM1)
Multiple Regression Test According to table (2), $\mathrm{R} 2=.292$ which means that KM1 explained $29.2 \%$ of variance in PM1. F value equal 8.911 with significant equal .000 , therefore we reject the null hypothesis and accept the alternative which indicate that there is an effect of KM1 on PM1.

The test shows there is positive relation between C5K and PM1 where Beta equal -.603 ( $\mathrm{t}$ equal 4.218, Sig equal.000).

Collinearity Statistics shows that the VIP values are less than 10 so there is no Collinearity between independent variables which indicate the power of study model.

\section{Second hypothesis:}

H0: There is no direct positive relationship between Artifacts Reusability (PM2), and the use of Knowledge Management (KM1) 
H1: There is a direct positive relationship between Artifacts Reusability (PM2), and the use of Knowledge Management (KM1)

According to table (4), R2 $=.495$ which means that KM1 explained $49.5 \%$ of variance in PM2. The $F$ value equals to 6.993 with significant equal to .000 , therefore we reject the null hypothesis and accept the alternative which indicate that there is an effect of KM1 on PM2.

Table (4) also shows that the Durban Watson test equal 2.052 which means that there is no autocorrelation in dependent variable.

Table (5) depicts which of the independent variable has a significant effect on PM1.

The test shows there is positive relationship between $\mathrm{C} 2 \mathrm{~K}$ and PM2 where Beta equal .310 ( $\mathrm{t}$ equal 2.905, Sig equal.004) and C4K and PM2 where Beta equal .380 (t equal 3.401, Sig equal.001)

From Collinearity Statistics the VIP values are less than 10 so there is no Collinearity between independent variables which indicate the power of study model.

\section{Third Hypothesis}

H0: There is no direct positive relationship between Scheduling (PM3), and the use of Knowledge Management (KM1)

H1: There is a direct positive relationship between Scheduling (PM3), and the use of Knowledge Management (KM1)

\begin{tabular}{|l|l|l|l|l|l|}
\hline Variable & $\mathrm{R}$ & $\begin{array}{l}\mathrm{R} \\
\text { square }\end{array}$ & $\begin{array}{l}\text { Durbun } \\
\text { Watson }\end{array}$ & $\mathrm{F}$ & Sig \\
\hline PM2 & .495 & .245 & 2.421 & 6.993 & .000 \\
\hline
\end{tabular}

Table (7) depicts which of the independent variable has a significant effect on PM3.

The test shows there is positive relation between C2K and PM3 where Beta equal .463 ( $\mathrm{t}$ equal 4.758 Sig equal.000).

\section{Conclusion}

Based on the results of the data analysis, there is reasonable certainty that the population of project practitioners surveyed, a perception exists that there is a positive relationship between the use of knowledge management and the improvement in the management of projects. The primary reason for this perceived positive relationship may be because knowledge management increases the likelihood of "awareness" of and "'"accessibility" of the knowledge available which improves the management of projects as well as the management of project risk. Risk management is the means by which uncertainty is systematically managed to increase the likelihood of meeting project objectives. Knowledge management enables a project team to reduce doing rework and compresses the time that it takes to plan projects. In addition, having the "right knowledge" to the "right person(s)" at the "right time" allows for greater control over the project through out the project's lifecycle by reducing uncertainty.

Based on the finding, the knowledge management processes of creation and codification were indicated as being most significant in terms of improving the management of projects.

The knowledge management processes indicated as most effective in improving the management of projects was knowledge creation and with knowledge codification followed by knowledge capturing with knowledge communication and then knowledge capitalization. It may be probably be that theses knowledge management processes were indicated as being most significant in terms of improving project management because most of the respondents to the survey came from the IT, ISP industries, and as aforementioned theses industries by there nature strive everyday to get the right knowledge to the right people at the right time to improve their organizational performance

\section{Limitations of the study}

The research was carried out with the intention of being as accurate as possible but it is acknowledged that limitations to the findings presented in previous chapters do exist.

1- The choice of population was limited to two industries, which has a tendency to limit the generalizability of the findings in the context of other industries. However, restricting the research to two industries may affect the concept of the generalizability of the result.

2- The choice of methodology was limited to one method of data collection (the questionnaire survey). It is acknowledged that, because of using surveys the researcher is not able to get 
the respondents to explain their responses, or for a particular response to ask the question 'why'. It is clearly indicted in the methodology chapter that it was beyond the research power, due to a number of constraints mentioned in chapter four, to choose multiple methods of data collection.

\section{References}

[1]Alkhaldi, F. M. (2003), "An Integration of Information Technology, cultureof knowledgetransferand innovative work environmentin support of organizational knowledge creation activities. Unpublished Phd, The University of Huddersfield. UK

[2]Barclay, Rebecca. and Murray, Philip C.(2004), "What Is Knowledge Management?" Knowledge Praxis.

[3]Bettoni, M. \& Schneider, S. (2002). The Essence of Knowledge Management, A More Appropriate Understanding of Knowledge. Basel University of Applied Sciences. Muttenz, Switzerland.

[4] Boucher, Karen D., Conners, Kyle, Johnson, Jim, and Robinson, James, Collaboration: (2001) "Development \& Management Collaborating on Project Success." Software Magazine, February/March
[5]Colgate, M. (1996). Information technology and sustainable competitive advantage:

[6] Davidson and Philip Voss (2002) Knowledge Management: An Introduction to Creating Competitive Advantage from Intellectual Capital. Tandem Press, Auckland New Zealand

[7] Drucker, P. (1993). Post-Capitalist Society. New York. Harper Business Dynamics.

[8] Garel G, Giard V, Midler C. (2002). Management de projet et gestion des ressources humaines.In Encyclopédie de Gestion des Ressources Humaines, ed. Allouche J, Paris

[9] Nonaka, I. \& H. Takeuchi (1995): The knowledge-creating company. How Japanese companies create the dynamics of innovation. New York: Oxford University Press.

[10] McElroy, Mark W. (2000). Integrating complexity theory, knowledge management and organizational learning. Journal of Knowledge Management, 4 (3), 195-203.

[11] Nissen, M.E. "Knowledge-Based Knowledge Management in the Re-engineering Domain,"Decision Support Systems 27, Special Issue on Knowledge Management (1999).

[12] Parikh, M. (2001, September). Knowledge management framework for high-tech research and development, Engineering Management Journal,13(3), 27-33. 